\title{
Pediatric Radiology Continuing Medical Education Activity: May 2008
}

\author{
Donald P. Frush
}

Published online: 13 May 2009

(C) Springer-Verlag 2009

\section{Erratum to: Pediatr Radiol}

\section{DOI 10.1007/s00247-008-0822-0}

For those of you who took the test between May 1, 2008 and March 14, 2009, you will have received an incorrect response to question \#7. The question and correct answer are listed below:

Which one of the following agents is FDA approved for use in infants (under 1 year of age)?
a. OptiMARK
b. MultiHance
c. Magnevist or Omniscan
d. All of the above

The online version of the original article can be found at http://dx.doi. org/10.1007/s00247-008-0822-0

D. P. Frush $(\bowtie)$

Department of Radiology,

1240 Huffman Mill Road,

Burlington, NC 27216

e-mail: frush943@mc.duke.edu 